\title{
MAN-LIKE GODS AND DEIFIED MEN IN MEXICAN COSMOLORE
}

\author{
Anna-Britta Hellbom
}

\section{INTRODUCTION}

\section{Ideas and theories}

This article can be read as an independent study specified in its title. However, put in a wider context it follows up a multidisciplinary project which was initiated in 1994 at the ICA (International Congress of Americanists) Symposium Anthropology 7 a on "Amerindian thought" - a topic that attracted researchers from different disciplines, let alone those with an interest for "overlapping" fields and with a zeal in initiating new ideas as well as those turning old stones over to view them from a different perspective or angle.

1. In my approach to that much discussed but too exclusively analysed topic I pondered on the necessity of avoiding - wherever possible - such western terms which might influence - even mislead a free discussion, deriving from traditional conventional categorising and systematising in accordance with monocultural and consequently irrelevant norms. E. g. Latin grammar as a model for linguistic studies, Greek philosophy formalising intellectual interpretations, Christian theological influences on cultural values - all leading to the conclusion that we have "religion" they have "a world view" or at best "mythology", etc.

My own paper focused on Nahuatl (Aztec) thought, using the term tloque nahuaque as a starting point for a discussion on similar concepts and comprehensive terms of "cosmic totality".

2. That "linguistic" angle I stressed on even more in a paper presented at the symposium organized by the Swedish Association of Americanists (SAMS) in September 1996, the topic of the symposium being "The Trickster". Querying the existence of such a figure outside its main geographic region, North America, and finding it 
there in its original scientific sphere, anthropology i. a., more "virtual" than real, in other words wishful thinking of some too enthusiastic categorisers, for my own approach I ventured to test "tricky outsiders" as an adequate designation of what I found in Mexico's past and present. On similar grounds and for the same reasons I preferred 'cosmolore' to 'folklore' for expressing what I wanted to test: a perception and a term without pejorative intimation.

3 . The present article follows up the same basic idea or opinion that in spite of realising that western researchers are influenced in their work by their own cultural patterns, we still incline to omit - often unconsciously - the strong influence of our own native languages, leading unintentionally to a misuse of our professional terminology when analysing and interpreting - let alone describing - other cultures.

The title of my paper is not just an expression of my desire for playing with terms, but a reflection of my attempt to exemplify some of man's perceptions of cosmic realities visualized in god-like images and conceptualised in traditional lore.

My ethnographic survey goes from pre-Aztec times to the post-revolutionary era - the 20 th century. It includes subjectively selected examples from texts on

(a) genuine gods benevolent and/or malevolent;

(b) divinised mothers of gods helping those in need; or ominous of disaster;

(c) deified humans often prominent leaders abiding their time to return;

(d) glorified individuals becoming heavenly bodies;

(e) legendary heroes as "deified men in being".

In my approach to such a multifarious topic I use 'cosmolore' - a term more suitable for the original socio-cultural context of the material.

In cultures with clear distinction between dogma and lore - established on the one hand by indigenous priesthood and on the other by westernised researchers - terms like 'folk' religion and 'folk' lore are authorized tools for scientific work. 
In Mexico where the Christian missionaries and monks soon realized that they met their intellectual equals in the tlamatinime 'learned men', and the teopixqui 'priests', the compilation of "religious data" in the indigenous languages started already in the 1520 's, thus giving later researchers authentic descriptions of the original patterns of thoughts, although expressed in western terms of value and categories. The authenticity, however, of the common people's beliefs has become much blurred by centuries of ideological indoctrination - already in late Aztec times.

This calls for interdisciplinary approaches and makes the linguistic aspect a must.

\section{Main protagonists and Chronology}

Due to the overwhelming multitude of conspicuous figures I have restricted my study to central Mexico, especially the so-called Valley of Mexico, and in the south to the Mayan area. During thousands of years peoples of all kinds were attracted to the central highland plains with their fertile soils, good water supplies and dense woods: nomadic hunters, sedantary farmers, military conquerors and others. Some of them stayed, others went further on, others again moved away to find other places to live on after a certain elapse of time. More and more products and ideas from other and more distant cultural areas were brought here through commercial exchange, social interactions, wars and other ways of contact.

My choice of protagonists aimed at finding adequate personages from such time period where historical - and even pseudo-historical - events initiated new eras by causing political, economic and social changes in the original cultural patterns. After a short survey of the epoch of the Otomí Indians those eras are

Toltec epoch: political hegemony in the Valley of Mexico, 12th century AD

Aztec epoch: geopolitical - military - expansion, 12th c. -1523

Colonial times: The Spanish Conquest - christianisation, 15231823

Independence: for the Criollos (1810) 1823-1910

Revolution: “... for Democracy, the posters said...”. 
Such a chronological arrangement may seem to contradict my ambitions to avoid wherever possible western methodology and terminology. My reason for this, however, is to facilitate for readers interested but not familiar with non-western history, in this case Mexico and its neighbouring countries, where the continuity of the past into the present is so strikingly near in time and real in mind if not always true. History based on "collective memories" needs some ordering to be understood by others. I have chosen chronology as the main guideline for my presentation.

As Octavio Paz (1990: 362-363) says:

Mexico is the land of superimposed pasts. Mexico City was built on the ruins of Tenochtitlan, the Aztec city that was built in the likeness of Tula, the Toltec city that was built in the likeness of Teotihuacán, the first great city on the American continent. Every Mexican bears within him this continuity which goes back two thousand years. It doesn't matter that this presence is almost always unconscious and assumes the naive forms of legend and even superstition. It is not something known, but something lived.

\section{THE FIFTH SUN OF CREATION - ERA OF MOVEMENT (OLLIN)}

\section{The Otomies - from hunters to soldiers}

The Aztecs were not the first to rule in the Valley of Mexico nor were the Toltecs. Among the various peoples inhabiting the fertile valley the Otomís were known as brave and feared warriors. Although living outside the real Valley region and in spite of their militant image they were dominated by other peoples, first the Toltecs and then theAztecs. Socially and culturally they were looked down upon by their conquerors, but recruited as elité-soldiers by the Aztec military forces and used as special guardians by their long trade merchants.

This is evinced by Fray Bernardino de Sahagún in his account on the Spanish Conquest. When the Spaniards came to the land of the Tlaxcallan their subjects 
the Otomi met them in battle; with shields and crossbows they moved against them, / --- / but they were completely overwhelmed and destroyed - with guns and iron bolts. /--- / And when thus the Otomi region of Tecoac had perished, those of Tlaxcalla could not control their alarm; they swooned with fear. /--- / Terror seized them. /---/ They summoned the lord's council and the ruler's council and they said: "How shall we act? Shall we perchance move against them? For, verily, a great warrior and brave leader is the Otomi /--- / In no time /--- / in but the flutter of an eyelid /--- / they destroyed the vassals [the Otomís]. So now let us make friends of the foe. [For] the common folk suffer." And thereupon the rulers of Tlaxcallan went to meet them [the Spaniards]. So great was their respect of the Otomi warriors. (FC, Book XII: 27)

More relevant here is what is known about the religion of the Otomís. Three principal gods are mentioned in the Códice Fuenleal: Yocippa, the Supreme God, and Otonteuktli - a deified human (Paso y Troncoso 1898: 190).

Sahagún describes them as follows:

The name of the Otomitl comes from, is taken from, the name of him who first became the leader of the Otomí. They say his name was Oton.

The Otomís had priests and their supreme priest was named Tecutlatca. They had also wise men whom they called 'Tlaciuhqui'.

He performed sorcery for [the god]; he was equal to, he resembled [a god]. /---/ He addressed the gods: he informed them of that which they desired. I---/

The people asked many things of the sorcerer: protection from war, sickness, famine, etc. They worshipped [sorcerers] as gods; hence they were very highly esteemed. (FC, Book X: 176-177)

Of special interest here is what Sahagún says directly of their Supreme God: "The name of their god was Iocippa" and that "his temple [was] very good (vel qualli in jteucal)," while on the other hand "the straw hut of trimmed and smoothed straw [was] called the temple of Oton (in teteçauhquj xacalli; in motocaiotia otonteucalli)." 


\section{"WHEN YET THERE WAS DARKNESS...”}

The gods assembled at Teotihuacán

when yet no sun had shone and no dawn had broken .... it is said ...

And they debated who would bear the burden, who would carry on his back - would become - the sun. I--- I

One of them Tecuciztecatl who was there spoke: 'O gods I shall be the one.'

Again the gods spoke: /--- / who else? / --- /

And not present was one man (ce tlacatl) Nanahuatzin ... listening among the others. They said to him: Thou shalt be the one, $O$ Nanahuatzin.

For these two, for each on singly, a hill was made (cecentetl intepeuh muchiuh). They are now called pyramids (tetepe tzacuilli) - the pyramid of the sun and the pyramid of the moon (itzacuil tonatiuh, yoan itzacoal metztli). I--- /

There they remained, performing penances for four nights. /--- / at the time of the lifting [of the penance], they were to do their labour (tlacolozque), they were to become gods (teutizque). I--- I

The gods spoke: Take courage, O Tecuciztecatl, fallcast thyself - into the fire. I--- / Four times he tried ... he could cast himself no more. / --- / thereupon they cried out to Nanahuatzin: Onward, thou, O Nanahuatzin. Take heart! fire].

All at once he quickly threw and cast himself upon [the

And when Tecuciztecatl saw that already he burned, then, afterwards he cast himself upon [the fire]. Thereupon he also burned.

And when the sun came to rise. /---/ Intensely did he shine, his brilliant rays penetrated everywhere.

And afterwards Tecuciztecatl came to rise following behind him from the same place - the east.

And so they tell it: Exactly equal had they become in their appearances as they shone. 
Then one of the gods came out running. With a rabbit he came to wound in the face this Tecuciztecatl; with it he darkened his face. Thus doth it appear today.

When both appeared [over the earth] together, they could - not move nor follow their paths. / --- / So once again the gods spoke: /---/ through us the sun may be revived. Let us all die.

Thus the sun cometh forth once, and spendeth the whole day [in his work]; and the moon undertaketh the night's task; he worketh all night.

Here endeth this legend and fable, which was told in times past, and was in the keeping of the old people." (FC, Book III: 1, VII: 4-8)

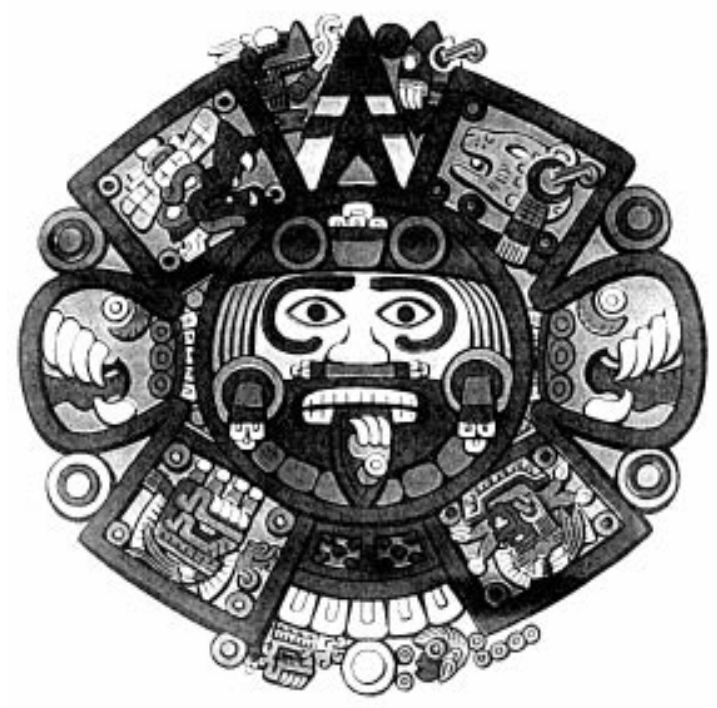

The Fifth Sun of World Age - created at Teotihuacán - is ruled by Tonatiuh, the sun: "the soaring eagle (quauhtleoanitl), the turquoise prince (xipilli), the god (teutl)" (FC, Book VIII: 1).

In the center of the so-called Aztec Sun Stone the face of Tonatiuh is seen surrounded by the signs of the previous destroyed eras simbolising their days and ways of destruction: Ocelot, Wind, Rain (of Fire), and Water. The Fifth Sun - the present age - will be destroyed by earthquakes.

Source of the illustration: Alfonso Caso "El Pueblo del Sol” (1953), p. 48. 
This may be seen as an indication that Otontecutli was the deified political leader worshipped later as a god of war.

In the light of such traditions whether historical or religious Sahagún's description of the final confrontation between the Otomís and the Spaniards makes the surrender understandable:

So the people of Teocalhueycan together with their relatives the people of Tliliuhquitepec consulted among themselves /---/ [and] agreed in a common determination to meet with and pray to the Captain - the god - and all the [gods]: "They have come to reach their revered home here at Teocalhueycan. Here we /---/ offer our prayers and greetings. - And may our lord hear (yoan ma qujmocaqujti in totecujo). For Moctezuma and the Mexicans have greatly afflicted and troubled us."/---/ (FC, Book XII: 71)

\section{The Toltecs - from warriors to intellectuals and artists}

After the gradual decline of Teotihuacán as the religious and cultural centre in the Valley of Mexico the Toltecs - whatever their direct influence in that process - took over the political leadership from the 11th century approximately. Their political centre and capital was Tollan/Tula. Among their many outstanding figures mythical and/or historic - are Huemac and Topiltzin Quetzalcoatl with the calendar name of Ce Acatl $=1$. Reed.

There are many different versions describing their images and they have been the subjects of much scholarly discussion for centuries as to their character, position and even existence, not the least who preceded whom as ruler of the politically expanding Toltec people. All this results in a rather blurred picture of the Toltec "history" (León-Portilla 1992: 375-76, Gonzalez 1990: 181 ff.).

The name of the most prominent ruler of Tula was 1 . Reed Topiltzin Quetzalcoatl. This last denomination indicates that he also may have been the supreme priest of that god. However, his fate seems sinister in that he was wheedled into committing two severe offences - that of drunkenness and then incest. Remorseful and in despair he gave up his high position as ruler and priest and left his 
country, however, declaring that he would return in power on the day of his birth - 1 . Reed.

Whether this frightening prophesy was pronounced by the god Quetzalcoatl or by his namesake the human supreme priest and ruler Ce Acatl Topiltzin Quetzalcoatl is irrelevant. His geopolitical successor in the Valley the Aztec ruler Moctezuma II when confronted with the approaching conquistador Hernán Cortés gave credence to the traditional prediction. The day when the Spaniards landed 1519 was Good Friday. Their captain and leader was dressed in black as was the Catholic custom, he was bearded and the date was according to the Aztec calendar Ce Acatl $=1$. Reed. All criteria of the authenticity of the returning god.

Huemac, in many sources referred to as the last ruler of Tula, had a gruesome story.

During his rule politics deteriorated into "despotism" (yn tlacaliztli) (Anales de Cuauhtitlan T II: 26) while violence paved the way for human sacrifices becoming an intrinsic part of religious performance. When finally the former powerful "state" collapsed, Huemac after a similar moral degradation as that of 1 . Reed, committed suicide at Chapultepec (Brotherstone 1992: 162).

He "reappears", however, referred to as "The King of the Dead" (Anales: 29) in a strange episode where he is visited by the messengers of Moctezuma II. He scolds them for their living and reproaches Moctezuma for his cowardice in planning to escape and hide rather than do penance and change lifestyle, thereby resisting what shall come according to the omens. All this Huemac tells the messengers in the image of an old soothsayer and wise man (Davies 1977: 236).

Irrespective of the identification problem of the two rulers and the relationship of the first mentioned to his namesake the god Quetzalcoatl all three personages exemplify how history - and pseudohistory - were exploited by later political leaders for their own aims of expanding both territories and power. 
The same legendary motives were merged into equally valued explanations in order to justify their new political programs. However, they all fell victims of failures due to tyranny and dictatorial extremes.

\section{The Aztecs - from immigrants to imperialists}

Conjectural history had a long tradition in Mesoamerica, and the Aztecs applied this selfglorifying method to the extreme, destroying the history of subdued peoples, while continually exploiting their knowledge! According to traditions told by the elder huehuete - the priest who led the migrant Mexica, was named Meçitli already when he was born (metl 'maguey', citli (tochtin) liebre) (Molina 1944: 23, 56).

And they placed him in a maguey leaf, where he grew strong; /--- / when he matured, he became a priest, a keeper of the god /---/ and all obeyed him by whom they were led /---/ (FC, Book X, Ch. 29, p. 189).

Among them were "wise men" (tlamatinime) called Amoxcoaque (ibid. 190) those who carried the god on their backs (in teumamaque). They carried the writings (in tlilli, in tlapalli), the books (amoxtli), the paintings (in tlaujlolli). They carried the knowledge (qujtqujque in tlamatiliztli), they carried all (mochi qujtqujque) - the songbooks (cujcaamatl), the flutes (tlapitzalli). Then they devised the book of days (in tonalpoalli), the book of years (in xioamatl), the count of the years (xippoalli), the book of dream (in temic amatl) /---/.

The history of it was saved, but it was burned when Itzcoatl ruled (1427-40). A council with the rulers of Mexico was held. They said:

It is not necessary for all the common people (mochi tlacatl) to know (qujmatiz) of the writings; the government will be defamed, and this will only spread sorcery in the land; for it contains many falsehoods. /---/ (ibid. 191).

The comment to this event by the learned scholar of Mexican history and cultures Frances Gillmor is worth quoting: It is interest- 
ing that the later burning of Aztec books by the Spaniards was not unprecedented (Gillmor 1964: 85, 136, 215 note 23).

Tezcatlipoca - "The Smoking Mirror" - Creator God, transformer, sorcerer.

He is one of the Supreme Creator-couple's four children and master of the First "Sun" or era.

He is both benevolent and malevolent, and consequently both feared and worshipped. He sees everything and influences even more. He is omnipotent as far as mankind is concerned.

Tezcatlipoca is the creator but he is also the destroyer, a bringer of fortune as well as disaster. According to the creation myth Tezcatlipoca is bereft his leadership of the world or universe by his brother and rival Quetzalcoatl. However, he is still the most prominent of the gods of ancient Mexico and keeps his influence over men.

He was considered a "true god" (vel teutl) whose abode was everywhere - in the land of the dead, on earth, in heaven (mictlan, tlalticpac, ilhujcac) (FC, Book I: 2).

On his frequent visits to Earth he transformed into a wicked sorcerer who brings ill fate to mighty men out of ill will and troubles everyone who provokes his capricious mood. He manipulates people to make mistakes and, even worse, to commit "sins". He was most destructive - and best known later - when he took the form of a wise adviser and bewitched and lured the mighty king of Tula to get drunk, commit incest and finally had to give up his leadership and withdraw.

He disguised in many different ways: human, animal and natural phenomenon, being a token of an omen of destruction:

the night axe (ioaltepuztli) / --- / which was considered portentous; / .-- / When the priests went forth to do penances - on mountain tops - then it was heard that it resounded like someone chopping and splitting wood. It rang out for a great distance; it much did frighten the people. /.--/ This night axe /.--/ took the form 
of Tezcatlipoca, to make sport and fun of people. (FC, Book V: 157)

Likewise all regarded the towering man (tlacahueyac) as an omen. It was seen as an apparition at night. It was said: "But all this is the disguise, the transformation of the demon Tezcatlipoca, with all of which he maketh sport of men (çan ie muche inaoal, inecuepaliz intlacateculotl tezcatlipuca, much ic teca mocaiaca)." (FC, Book V: 175)

Tezcatlipoca also took the disguise of different animals like the coyote, the racoon and the skunk. This last mentioned animal was shunned both for his omen of death and for his evil smell (epatl 'cierto animalejo que hiede mucho', according to Molina 1944: 29). When it entered someone's home (ichan) or bore its young there, they said: "Now the householder will die".

Also they supposed that it was the likeness of the demon Tezcatlipoca (ca ixiptla in tlacateculotl, tezcatlipuca) / when it loosed an odor, a foul odor (in jquac mjexi, in teiexi). Then they said: "Tezcatlipoca breaketh wind" (qujtoaia: omjex in tezcatlipoca) (FC, Book V: 171).

Another portent omen was the so-called "bundle of ashes" (tlacanexqujmilli - nextli 'ashes'; cf. Molina 1944: 72).

When it was seen, it only went rolling, groaning and billowing. /---/ He who saw it then held it as an omen that he would die, either in war or of some sickness, or that something evil would meet and fall upon him (FC, Book V: 177, cf. n.1).

Also the dead appeared to people. They were in [funeral] wrappings, with head wrappings, and were groaning. /--- / Only the valiant could venture toward in order to seize it. /--- / But then it only made sport of them: perhaps a clump of grass or a hard clod remained in their hands. Thus they quickly transformed themselves. /---/ (FC, Book V; 180)

And thus it was said:

indeed, all this is the disguise, the reappearences, the apparition of Tezcatlipoca /---/ by which he mocked men./---/ (ibid. 177) 
As Tezcatlipoca's last performances or interventions on earth in pre-Hispanic times there are two episodes worth mentioning described by Sahagún in the 12th volume referring entirely to the Conquest:

And when [the Spaniards] came / ---/ first they had come upon and seized a man from Cempoalla (ce tlacatl, Cempoalla), named Tlacochcalcatl (itoca tlacochcalcatl) /---/ He also was an interpreter (oalnaotlatotia) and set them on their road, put them on their course, showed them the way, led them along, and acted as their guide. (FC, Book XII: 27)

It is well known that the Aztec warriors of the highest grades had the title of 'tlacochcalcatl' (Moreno 1962: 120, referring to Durán) "titles in use long before the Aztecs and that /---/ they reflect an older system of social organization" (Townsend 1992: 196, cf. Schultze-Jena 1957: 303-305, 315-334).

What intrigues me is the nahuatl 'itoca' which Anderson and Dibble translate as 'named'; however, in my opinion it could also be interpreted as 'his name [was] Tlacochcatcatl' thus referring to a person. Could that "person" have been the sinister Tezcatlipoca? Or is it just my wishful thinking?

In the text on the second episode Tezcatlipoca is actually mentioned as the protagonist in disguise.

Once again Moctezuma sent more messengers (titlano $(l) i)$, soothsayers (tlaiiuhq) and magicians and also fire priests (tletlenamacaque) to stop the Spaniards casting a spell over them. But they failed.

For a drunkard (tlaoanquj) came along the way. They beheld him as one from Chalco, for so he was arrayed. /---/ Like one besotted, he bore himself and acted like one drunk. / -.-- / He accosted them, having come ahead of the outposts of the Spaniards.

And he rose up against them and said: "What do you come to do here again? / ---/ What would Moctezuma yet wish to do? /--- / he hath committed a fault. He hath abandoned the common people; he hath destroyed men. / -.- /" 
The messengers /--- / tried to soothe him praying humbly to him and quickly setting up his abode /---/ his earth pyramid and his straw bed. /--- / vain was its erection.

Just as if they had plunged him into his rage, he presently chided and abused them and spoke harshly.

"Why will you vainly stand there? No longer will there be a Mexico; [it is gone forever] it no more existeth. / --- / look at what befalleth Mexico /--- / "Then they saw that the temples (teucalli), the tribal temples (calpulli), the priests' dwellings (calmecatl), and all the houses in Mexico burned. Seeing this disaster it was as if they had lost heart; /--- / They said: "This is not for us to see; it must needs that Moctezuma see what we have seen. For this is no common being; this is the youth Tezcatlipoca" (ca amo çan aca, ca iehoatl in telpuchtli Tezcatlipuca).

Then he vanished, and they saw him no more. (FC, Book XII: 34)

And so the messengers went further to encounter the Spaniards.

There are many parallels to beliefs and features ascribed to Tezcatlipoca - and other ancient gods, for that matter - found in Mexican present-day lore. One of his spectacular paraphernalias is the obsidian mirror he wears on his head - in other versions also on his left foot. The Huichol of Nayarit today consider the circular glass mirrors as supernatural passageways as well as representing symbolically the Sun, Moon, eyes and flowers, just as the peoples of Teotihuacán a thousand years earlier saw them as similar symbols also of "a world that could be looked into but not passed through" (Miller \& Taube 1993: 115).

Quetzalcoatl. Tezcatlipoca's brother and rival; benefactor

Quetzalcoatl became master of the Second "Sun" of the five eras of the world creation. He is often referred to as the "cultural hero". He brought the human bones back from Mictlan, the realm of death, and he gave mankind their most important food: corn, both deeds after overcoming obstacles and fighting hostile guards. 
However, Quetzalcoatl is more than this image of a cultural hero he is a god, and one of the most potent as to influencing mankind mainly to their benefit. Thus he is quite the opposite to his brother Tezcatlipoca and venerated for his goodness, seldom feared. He is evocated by leaders and rulers, by warriors but also by the common people (macehualtin).

His story is fused with his namesake the king of Tula Ce Acatl Topiltzin Quetzalcoatl in that many of the legends told about the one have merged in those of the other. For centuries this fusion of identities blended into a confusion in that different sources tell different stories about what might be one and the same personality (cf. Esplendor del México Antiguo I, 1959). Their early life stories are almost identical as to the miraculous birth of both the god and the human ruler also called Pontifex Tonitzin in the Anales de Cuahtitlán. His mother is said to have swallowed a precious stone (ynantzin Quetzalcohuatl chalchihuitl quitollo). This happened in the year of 1 . Reed and his mother's name was Chimanal (Anales del Museo Nacional T. III, 1886: 13f. Sp. trad. G. Mendoza y Felipe Sanchez Solis).

In the year 9. Reed he went looking for his father - at this age of nine he was quite prudent - but his father was dead. So he tried to find his father's bones in order to bury them in his own palace.

In the year 5. House the Toltecs called for Quetzacoatl to become their regent and also to be the high priest (el gran Sacerdote/yn Teopixcauh catca) (ibid. 15).

Due to rivalries between political groups in Tula/Tollan and because some were especially irritated that Quetzalcoatl was against human sacrifices (no se atrevía él jamás a sacrificar a los hombres nacidos en Tula), the "demons" (demonios, Tlatlaxacatecollo) made jokes about him and they mortified him in order to make him leave /---/ (ibid. 17).

And the same demons (Tlatlaxacatecollo) agreed to call upon assistance of Tezcatlipoca. Disguised as a young man he told the guards to tell Quetzalcoatl that a young man had come to show him his image (monacayo, monacayotzin) (ibid. 18). Then he gave him a mirror (tezcatl) saying "Here know yourself which emerges from your own flesh (carne) just like it emanates from the mirror 
(tezcatl)." Seeing himself - as they had painted him grotesquelyhe got frightened and so alarmed that he left the room (ibid. 19).

Then the demon proceeded to invite him to drink wine (octli) saying: "To drink four glasses will do you no harm (con las cuatro tomas no muere)." But they gave him also a fifth glass in honour of his authority.

And Quetzalcoatl felt very much at ease (gozaba sintiendo un bienestar indefinido) (ibid. 19).

And then the demon made him sing and very happily Quetzalcoatl sang and said: "Bring my wife Quetzalpetlatl (nopiltzin cihuapilli Quetzalcoatl) and let's enjoy ourselves together /---/!"

Afterwards he felt bitter remorse and his shame had no measure. And this same year of his birth, 1. Reed he left his country. And when he came to the sea, he ordered a funeral pyre to be lit and he threw himself into the fire. And when they gathered his ashes, several beautiful birds assembled around the pyre (ibid. 21). And from the ashes of his heart (yn iyollo) his spirit arose as a star and it reached the heaven. This is the star that appears in the mornings to bring joy to the homes and the houses; it was called Tlauitzcalpan.

But after his death he did not appear in heaven for eight days, because he went to hell (mictlan) first. But after eight days (chicueylhuitica) he appeared as a huge bright star (huy citlalli).

And it was said that then he was deified (él quedó divinizado, moteuhtlali) (Versión trad. Mendoza \& Sanchez Solis) or then Quetzalcoatl reached his supreme position (fué cuando Quetzalcoatl tomó su asiento real) (Version trad. Galicia Chimalpopoca. Ibid. 22).

There are two interesting parallels in the eschatological accounts of Tezcatlipoca and Quetzalcoatl: both are transformed after death into heavenly bodies, in Spanish 'astro' which also means star.

The Mexican historian and archaeologist Alfredo Chavero points out in his analysis of La piedra del Sol based on the description of Torquemada (Anales del Museo Nacional, México 1886, Tomo III: 
23 Torquemada: t. $2^{\circ}$ p. 40 ) that Tezcatlipoca has characters of both the Sun and the Moon. On earth he walks around in the form of a beautiful young man (Telpuctli sic) observing and revealing the "secrets of the night" (Chavero 1886: 23). So they put out icpalli on the streets, the roads and at the cross-roads for him to rest, seats that nobody dared to use! They were called 'momaztli' of 'ichialoca: $y$ eran para que descansase el astro en su curso' ('for the star to rest'). But for the people (para la multitud) they were real resting seats for the very god in a person (eran verdadero descamso de la persona del mismo dios). And Chavero comments: "The celestial body was transformed into a god and the god in a person (el astro se convirtió en dios, y el dios en persona)" (Chavero: 23). According to Chavero the star in question was the Evening Star, Tezcatlipoca being related to the night.

However, both the Evening and the Morning stars were related traditionally to Quetzalcoatl, whose divine identities fused with the personality of the ruler of Tollan and the supreme priest. Consequently his official dress and paraphernalia were the costumes and functions of the star Quetzalcoatl. The star that died in the evening would reappear in the morning in the East: thus the tradition was transformed to reality and the prophesy of the return of the king/priest of Tollan would be from the Orient. "Nobody doubted this in Mexico; Moctezuma II was convinced that when Cortés landed on the eastern shores of Mexico, he was the returning god." (Chavero: 24)

Huitzilopochtli - "Hummingbird on the left (south)" - from political leader to God of Sun and War

Huitzipochtli is the only divinity of Aztec origin in the pantheon of Ancient Mexico. He was "only a common man, just a man (tlacatl)" (FC, Book I: 1). The etymology of his name has been much discussed. 'Huitzilli' is the 'hummingbird' (or 'colibri') and 'opochtli' means 'left' but also 'sinister' (malignant) (Santamaría 1959: 606 siniestro, zurdo).

The verb 'opochiua', 'nitla' means 'to make something with the left hand' (hazer algo con la mano izquierda; cf. opochmaitl 'mano izquierida', Molina: 78; icxjtl 'foot', ibid. 34). Huitzilopochtli is de- 
scribed thus by Sahagún. "And on his thin foot, his left, he had the sole pasted with feathers (auh pitzaoac in jcxi yiopochcopa)" (FC, Book III: 4).

The Franciscan monk says further:

And Uizilopochtli was also known as an omen of evil; (Auh Vitzilobuchtli no mjtoaia tetzavitl; cf. Molina: Tetzauitl, cosa escandalosa, o espantosa o cosa de aguero, p. 111) because from only a feather which fell, his mother Coatl icue conceived. For no one came forth as his father (ichica ca çan juitl, in temoc injc otztic in jnan in coacue; caiac nez in ita) (FC, Book III: 5).

The traditional conventional interpretation is that opochtli is related to the south, probably, however a reconstruction of the legend that dead warriors carried the Sun from the east to the zenith where they transformed into hummingbirds! - a poetic and plausible explanation considering that Huitzilopochtli became their God of War but he was also seen as the Sun. Consequently the Aztecs saw themselves as the People of the Sun.

The story of Huitzilopochtli's miraculous "birth" I have summarised from Sahagún's FC Books I and III:

The following they believed of his beginning. /--- / At Coatepec, near Tollan, /---/ there lived a woman (cihoatl) named (itoca) Coatl icue, mother (innan) of the Centzonhuitznaua [the four hundred from the south or southerners] /--- / And their elder sister (auh inveltiuh itoca) Coiolxahquj. / --- / (FC, Book III: 1). And this Coatl icue performed penances /--- / sweeping [in the temple] at Coatepetl. / --- / a ball of feathers descended upon her /---/ which she /---/ placed in her bosom (en el seno junto a la barriga). Thereupon Coatl icue conceived. (Quetzalcoatl is in some stories also said to have been miraculously conceived - a virgin birth. FC, Book III: 1 , notes 4,5 )

Now her other children were angry with the mother:

she hath affronted us, we must slay our mother, the wicked one who is already with child. Who is the cause of what is in her womb? 
Cotl icue became frightened / --- / And her child who was in her womb spoke to her "Have no fear (maca ximomauhti); already I know (ie ne nicmati) /---/ (FC, Book III: 2). And the Centzonnuitznaua /--- / prepared themselves for war /--- / Thereupon they set forth; they went in order, in columns, in armed display moving with deliberation. Coyolxauhquj led them. I--- /

But Quauitl idae [their uncle i.e. Coatlicue's brother probably] warned Huitzilopochtli all along their advancement /--- / When he asked "watch where they now come." /--- / Finally Quazitl said: "At last they are coming up here, at last they reach here. Coyolxauhquj cometh ahead of them."

And Uitzilopochtli burst forth, born (njman jc callat). (FC, Book III: 3)

With the 'xiuhcoatl' - fire serpent - he pierced Coyolxauhquj and

/---/ struck off her head. Then he pursued the four hundred [brothers] and killed them / --- / few escaped the hands of Uitzilopochtli /---/. (FC, Book III: 4)

The migration story of the Aztecs is summarised from different versions shaped over long times and based on political facts and fantasies along with religious visions. On Huitzilopochtli's order they changed their name from Aztecs (Aztlan was the name of their mythical point of departure) to "Mexica". He told them: "Now you shall not call yourselves Aztecs any more, now you are Mexicans." And his gifts to the people were the arrow (mitl), the bow (tlahuitolli), the spear-thrower (atlatl) and the "little net" (chitatli) (Davies 1977: 7; see also Tezozomoc 1949: 23; cf. Molina 1944: 22 chitatli 'redezilla para lleuar de como por el camino').

The migration is said to have started aroundA. D. 1111 fromAztlan. The people few in number was led by four priest-leaders (teomamas) i.e. "bearers of the god":

They had an idol [sic!] called Huitzilopochtli, who was borne by four guardians who served him; to these he spoke very secretly of the events of their route and journey, telling them of all that was to happen. And this idol was held in such awe and reverence 
that no one else but they dared to approach or touch it. (Davies 1977: 8)

And everywhere they stayed they were told to "build temples and erect the dwelling place of their god Huitzilopochtli" (ibid. 10, 20; an oratory 37 ). All through the sufferings of the hard migration times they were constantly encouraged by the promises of a glorious future told them by their priests who learnt of it in dreams sent by the god.

These were said to be the words of the god speaking to his chosen people:

we shall /--- / establish ourselves and settle down, and we shall conquer all peoples of the universe; and /--- / I will make you lords and kings of all that is in the world; and when you become rulers, you shall have countless and infinite numbers of vassals, who will pay you tribute / --- / precious stone, gold, quetzal feathers /---/ and multicoloured cacao and cotton; and all this you shall see, since this is in truth my task, and for this have I been sent here. (Davies 1977: 10)

The migration story - as the political history - of the Mexica is filled with extraordinary sufferings caused by their enemies along with shuddering cruelties from their side in self-defence in order to survive, but also fighting for power - all following the orders of their god Huitzilopochtli. Whether apocryphic or partly based on cultural facts the most gruesome story is how they lured the ruler of Colhuacan to give his daughter as wife to their god. Then they killed her, flayed her and the priest donned her skin according to the ceremonial rite for the fertility. Moreover they invited the unsuspecting father, Achitometl, to take part in the ceremonial festivities in honour of the "goddess" (Davies 1977: 33)

However apocryphic this story it gives in a nutshell their aims and methods: to become respected even through horror.

Naturally the Mexicas were expelled but they won their purposes in accordance with their political model: military conquest, ruling with terrors and social acceptance by marrying into the most prestigious families of the sedentary population in the Valley. 
In 1325 - alternatively 1345 - theAztecs/Mexica founded there capital Tenochtitlán on the place that Huitzilopochtli has anticipated to them in the sight of an eagle - symbol of the Sun - perched on a cactus plant with a serpent in his beak.

The rapidly expanding powers of the Aztecs - political, territorial, economic - lasted for about two hundred years.

Their principal symbol is seen as a national emblem in the centre of the Mexican flag.

\section{Coatlicue - "Serpent Skirt", mother of Huitzilopochtli}

The miraculous conceiving of Huitzilopochtli by a feather ball from above entering the womb of his mother to be, makes Coatlicue a goddess whatever her original existence.

Thus it was told of his beginning, his coming into existence in the words of Sahagún: "/---/ from only a feather which fell his mother Coatl icue conceived. For no one came forth as his father" (FC, Book III: 5).

In some variations Coatlicue is ascribed the motherhood of Topiltzin Quetzalcoatl which makes her status terrestrial. As the ruler of Culhuacan she may have supported her son's ambition to achieve the rulership of Tollan (Gillespie 1989: 148, 151, 176). This, however, might be a reconstruction based on pseudo-historical facts with the view of apotheosising a political leader, whose predecessor's wife happened to have the same name as the earth goddess.

A noteworthy coincidence to consider is the similarity of the moral admonition that Huemac gave to the messengers of Moctezuma (II) Xocoyotzin and the one given to the messengers of Moctezuma (I) Ilhuicamina by Coatlicue. She appears to them with sorrowful prophesies about the coming decline of her son's chosen people, the Aztecs. Following the text of Frances Gillmor the group of messengers was led by an old man to the top of the hill

where the mother of the Hummingbird on the Left still lived. He went right up the steep slope of the hill /---/ but the Tenochca 
[Aztecs] went slowly /--- / They stopped and were helpless. And the ancient mother of their god came to them. /--- / And she said to them "Because of these foods and this rich cocoa you are weak. Because of them you could not climb the hill." And she said /--/ "My son will come to me again. He took two pairs of sandals one to go away and one to return. He said that he would conquer many cities in their order, and in the same order lose them. Let him come soon..." / --- /

The priests and sorcerers laid gifts before Moteczuma that she had sent to Huitzilopochtli, her son-not jewels but a mantle and breechcloth of maguey fibre, such as the poor wore and the soldiers on the march /--- /

The king who had sent jewels received the simple gifts /--- / and he commanded them to be sent to the temple of Uitzilopochtli, as the gift of his ancient mother who remembered that he had taken one pair of sandals to stride forth to victory, and another to return in defeat. (Gillmor 1964: 187-188, 240 n.17; from: Fr. Diego Durán Historia de las Indias de Nueva España, Vol. I: 218-228, México 1867, 1880. Written about 1581)

Cihuacoatl - "woman-snake", earth goddess and patroness of midwifery, later title of the Aztec ruler's co-regent

As earth-goddess Cihuacoatl takes part in the creation of mankind. When Quetzalcoatl returns from the underworld, the realm of Mictlan, he takes the stolen bones of the previous human figures to Cihuatlampa, i. e. the abode of the earth-goddess in the West, Cihuacoatl. She grinds them on her stone mortar (metate) to a fine meal on which the gods sacrifice blood from their penises. From this dough a new human race is formed to live and shape the fifth and final - "Sun" or era (cf. Clendinnen 1991: 173).

As patroness of childbirth, the midwives direct their speeches to the child-bearing women exhorting them to ask Cihuacoatl for help in their needs and to struggle like warriors in their efforts to give birth. As she was also the patroness of the sweathouse (temazcalli) the woman was taken there as a last resort and if dying finally left to die alone. It was believed that after death these women took over the Sun from the dead warriors in the zenith to lead it to the west. 
In his documentary works Sahagún mentions several times that during the rule of Moctezuma Xocoyotzin (the Younger)

when the Spaniards had not yet come to this land /--- / signs and omens /---/ appeared. As the sixth omen it happened that the (demon) Ciuacoatl went about weeping, at night. Everyone heard it [sic!] wailing and saying: "My beloved sons, now I am about to leave you." (Nonopilhoantzitzi, ic çan namechnocaujlia.) (FC, Book VIII: 2).

In the same book he relates however, the same saying thus:

/---/ [As] a sixth omen /---/ was heard a woman crying out in the night "Now we are at the point of going! Whither shall I take you?" (FC, Book VIII: 17, 18).

And he repeats the augury thus:

/---/ often a woman [sic!] (cioatl) was heard [as] she went weeping and crying out. Loudly did she call out at night. She walked about saying " $O$ my beloved sons (Nonopilhoantzitzin) now we are about to go!" Sometimes she said: "Whither shall I take you?" (FC, Book XII: 2-3).

Centuries later this aspect of Cihuacoatl merged with the wellknown figure called La llorona who is heard wailing and crying for her lost child. The legend behind this phenomenon is a Mexican folktale with details from both native and European origin (see also Cihuateteo below).

At the accelerating expansion of their realm in the middle of the 15th century, the Aztecs institutionalised the charge of a co-regent as the adviser to the ruler (tlatoani). His functions were to take over the civil tasks of the ruler in wartime. He continued, however, as his chief advisor which no doubt included planning, organizing and even taking part in battles as a military leader. He was also president of the Supreme Court and he functioned actively in religious rites and official administration. And he was supervisor of the tributary organization (León-Portilla 1992: 276-77, 278). 
His title cihuacoatl has given cause to much scholarly discussion. It has even been suggested that his title might emanate from a berdache institution (cf. Clendinnen 1991: 169). More likely though, in my opinion, that the ancient religious philosophy of a fusion of both sexes into one divine personality is the basis of giving the title of a female goddess and earth mother to a male politician, who furthermore very likely may have acted as the high priest of that same goddess, in this case the earth mother Cihuacoatl (cf. Gillespie 1989: 62 ff.). I also refer to Miguel León Portilla when he says

As a reflection in the political organization of the religious belief of a dual Supreme God [Ometeotl/Omecihuatl] the so-called cihuacoatl "Serpent woman" or "female twin" held several extremely important assignments" (Como un reflejo, en la organizatión política, de la creencia religiosa en un supremo Dios dual, al lado del Huey tlatoani, desempeñaba también funciones en extremo importantes el llamado cihuacóatl - "serpiente femenina” o "mellizo femenino"). (León-Portilla 1992: 276)

Cihuateteo-mociuaquetzque; - from "female warriors" to "Women Gods"

After death the souls of the women who died in childbirth were risen to those celestial regions from zenith to the west where they carried the Sun entrusted to them by the souls of the male warriors who died on the battlefield. They were thus equal to the men who captured an enemy and they were called mociuaquetzque giving the act of birth the same value of bravery as the death of a fighting soldier. Consequently the bodily remains of such a woman were highly estimated as a talisman for bravery and success in battle (Miller \& Taube 1993: $61 \mathrm{ff}$.).

However, these women also called Cihuateteo (Women Gods), were much feared as they were believed to attack especially children at cross-roads at night. They also lured men to commit adultery or sexual indecencies (ibid. 62).

About these celestial but former terrestrial creatures Sahagún writes in several of his books: 
And these little women (cioatzintli) who died in childbirth, those said to become mociuaquetzque, when they died, they said to have become goddesses (in jquac oonmjc in qujtoa oonteu).

And the midwife spoke to the dying woman:

"Go, accompany our Mother, our Father, The Sun! (in tonan, in tota, tonatiuh) May his older sisters, the ciuapipiltin, the celestial women, bring thee to him / --- / For thou will forever live, be glad, be content near (om jnnaoac) [and] by our goddesses, the ciuapipiltin (totecujiooan cioapipilti), and already thou livest by [and] near our lord (inao intinemj in totecujo) for already thou beholdest the lord. /--- /

Pray for us, intercede for us (xitechmotlatlauhtiliti, ma xitechnochili) /---/ (FC, Book VI: 164)

There are many beliefs in omens and auguries related to space and time emanating from the cihuateteo.

In his book IV "Soothsayers and omens" Sahagún writes:

/---/ the nineteenth sign, named One Eagle /--- / was an evil day sign (tonalli) /--- / Also at that sign descended those named the 'Goddesses' (uncan temoia in qujn tocaiotia cihoateteu) or later below he says at this time descended the lesser Goddesses (oaltemoia yn aquique tepitoton cihoateteu); and they did evil to the small children (auh quintlaueliaia in conetotonti).

And he continues

Hence they did not let them go out of doors, nor did they bathe them. I--- / None of the small children might go naked. They were carefully watched because at this time they might be violently possessed, their lips twisted, /--- / eyes crossed /--- / noses crooked, etc. /---/

The same warnings were pronounced also for the day One Rain.

Hence most sternly [parents] commanded (qujntlaquauhnaoatiaia) their children (in tepilhoan) not to go out; not to travel along the roads... (FC, Book IV: 41)

You will encounter the Princesses (in cioapipilti) for they will descend upon the earth. 
And therefore they paid them great honour there in the places where they awaited, there in the different Goddesses' temples (cichoateucalco - calli house). In each neighbourhood, in the house clusters and their vicinities, reeds were strewn and scattered; sand was sprinkled (tlaixalhujlo yn vtlica) on the roads and at street crossings and crossroads-places where roads came together.

One who made a vow to them that he would cover and wrap them, adorned their offerings, the paper banners of the Goddesses (in cihoateteuitl amatl). /--- / There he covered the different images (yn inixiptlaoan) of the Goddesses, as they were arranged in order.

It was at midnight, just at the dividing of the night (iooalnepantla), that the making of offerings began. And when it ceased, it was noon (nepantla tonatiuh). (FC, Book IV: $107 \mathrm{ff}$.)

Further omens (in tetzaujtl) Sahagún describes in Book V saying:

/--- / when at night, someone heard some wild animal cry out, or when it seemed as if some old woman wept (ilamachocaia), when anyone heard that / --- / a wild beast howled at him like one who blew a shell trumpet, and the mountains answered him. It wails; [a sound] issued from its mouth, as if a poor woman wept (ihujqujn ilamapul choca). (FC, Book V: 151)

Finally he tells about the rest of the omens occurring at night - an omen of death (in mjquiz tetzaujtl). Also called "hunched shoulder" (itoca cujtlapanton) and they showed themselves to men only at the latrines, the dung heaps (cuiatl 'excrement') (FC, Book I: 6) -

And thus did it look - like a little girl (civapiltontli) indeed quite small (çan vel tepiton), not a bit tall (amo achi quauhtic). He to whom she appeared could not catch her /---/ she only mocked him. / --- / So he only let her alone, in terror. (FC, Book V: 170)

How much and in what aspects the pre-Hispanic traditions of the cihuateteo have influenced the beliefs of later centuries in the legendary "La Llorona" (The Wailing Woman) is still an open question (Cf. i. a.: Kirtley 1960). 
The encyclopaedist Santamaría declares about this dramatic figure thus:

She (or it) is a phantom, created out of popular imagination, which frightens the inhabitants as they believe them to be souls in agony (almas en pena) while in reality they are nothing but just youngsters in disguise. Further he points out that while the wailing and crying is referred to the howling of coyotes and wolves by young people, the old ones are sure that it is "la llorona". They refer the sounds to a lost soul and humbly make the sign of the cross for protection. (Santamaría 1959: 671, quoting Luis Gonzalez Obregón Vestusteces. Méjico 1917: 96)

Mayahuel - from celestial girl to deified woman and goddess of pulque

Mayahuel is the woman who found out how to transform the juice of the maguey (agave) plant into an intoxicating beverage - a drink to the joy for men and women and accepted by the gods as an equal in their pantheon.

As a goddess she is depicted mostly sitting in the middle of a maguey, sometimes with a suckling child on her lap - an image likely referring to the rich sap of the plant - the milky "honey water" (aguamiel). She is also denominated as "the woman of four hundred breasts" which relates her to the Centzon Totochtin "Fourhundred Rabbits", the gods of fermented alcoholic drink pulque (octli).

One myth out of various different versions of the traditions, relates that together with Quetzalcoatl in his appearance of the wind god Ehecatl, she runs away from her celestial home chased by the dangerous tzitzimime or star demons. Accompanied by Quetzalcoatl she hides disguised as branches of a tree. But she is found and torn to pieces by the pursuers. Quetzalcoatl buries her remains from which the first maguey grows (Miller \& Taube 1993: 112) 
The description of the discovery of the pulque, the fermented maguey juice, according to the British researcher's C. A. Burland's lively text - too charming to be resisted - runs as follows:

The story goes that in ancient times Mayauel was the wife of a farmer. On going into the field one morning she saw a mouse. Farmers' wives usually kill mice, but this one escaped because he could not run away. He was running around in circles, but he showed no fear. He just looked at Mayauel, and said something that he thought so funny that he laughed himself off his feet and went to sleep. The lady looked around to find the cause of his extraordinary behaviour, and saw that he had been nibbling the stem of a maguey cactus where some sap had collected that looked strangely cloudy. Mayauel collected some more sap in a gourd and gave it that night to her husband. He approved of the drink and did much more than run around in circles, so that his wife came to prove of it too. /.--/ the happy couple were able to introduce the drink to the gods, who kept Mayauel with them as goddess of Pulque, and her husband Xochipilli as lord of gambling. (Burland 1953: 28)

According to the more matter-of-fact description of Sahagún's informants the production of pulque was due to the collaboration between wife and husband. Thus he writes:

The name of the woman, who for the first time discovered the boring of the maguey (metl) was Maijauel (itoca Maiauel, ca cioatl) but the name of the one who discovered the stick, the root, with which wine was made was Patecatl (auh in quittac tlacatl, tlanelhoatl, injc mochioa vctli, itoca Patecatl). And those who made, who prepared wine (vctli) the name of one [was] Tepuztecatl among four hundred pulque gods!" (FC, Book X: 193)

Tezcatzoncatl - "the god with a mirror in his hair"; from pulque god to local patron and later political leader as "El Tepozteco"

Tezcatzoncatl is one of the numerous pulque gods, the four hundred rabbits (centzontotochtli $400=$ a great many). Others were 
Ometochtli and Tepoztecatl, however, Tezcatzoncatl is more related to human than godlike morality. "He was the wine" (Jehoatl in vctli).

He had an intensive influence on human life, not directly but symbolizing ethically the consequences of excessive drinking of pulque. In Sahagún's description he is not wandering on earth like Tezcatlipoca, but perceived by the adherents as an "awesome being" who may sway the imprudent into committing indiscretion, misbehaviour and even crimes. For he hurled people off crags, he strangled people, he drowned people, he killed them /--.- / one did not speak lightly of him /---/. (FC Book I: 24)

It is obvious that Tezcatzoncatl was the main symbol of the intoxicating beverage, pulque (vctli) and a warning of its effect leading to drunkenness which was considered a vice of the highest immorality. Only old people were permitted to get drunk.

Sahagún emphasizes his warnings in an appendix to Book I:

Woe unto them that thus lived; even greater woe, if some even now persist in doing this. For the devil will carry off their souls (ca diablo qujnvicaz yn jmanjma). (FC, Book I: 44)

This may be compared with his condemnation of those who continue worshipping the mountain gods - Tepictoton:

And indeed [the observance] is not now completely uprooted /--- / And this is a mortal sin (vei tlatlaculli), a great offence to God (vey yiolitlaculoca yn dios), a great heresy (vey eregia). It is an abominable sin (ca tetzauhtlatlaculli). (FC, Book I: 45)

The editors of the English edition of Sahagún's work point out as an indication of "the time when Sahagún must have worked on the Appendix to Book I:

y esto aun no a cesado, que este año pasado, de 1569, yendo vnos religiosos /---- sobre la sierra de toluca /---/. hallaron /---/. vn sacrificio /.--/ muy reziente, de cinco, o seys días hecho /.--/. (FC, Book I: 45, note 132) 


\section{THE COLONIAL ERA - NEW LORDS AND OTHER GODS FOR THE NATIVES}

The conquistadors of the first generation were eager to gain their ends and have all that was denied them in their homeland: gold and land to make them rich, goods and products to sell and export, labourers and servants to work for them and souls to save from purgatory and hell, their own included.

The professional politicians were too few to carry out the imperial orders of evangelisation and urbanisation which meant education and integration of the indigenous. In order to protect the Indians the Spaniards were restricted to the new towns and cities. However, the Indians were not stopped visiting the new urban centres. More contingents of immigrants crossed the Atlantic including women. Soon enough a new social class emerged - the mestizos, the social scale of which amounted up to sixteen "groups" each with its descriptive denomination.

However well planned from Madrid and Sevilla the control of the socio-economic situations in the colonies was insufficient, to say the least. Such were the circumstances that came to model the society for the proximate three hundred years.

To illustrate the Colonial times I have only a few subjectively selected examples based entirely on the work of the French scholar Serge Gruzinski "Man-Gods in the Mexican Highlands. Indian Power and Colonial Society, 1520-1800" Engl. version Stanford University Press, Calif. 1989. From his book I have chosen five figures from different epochs and with different social backgrounds and life stories.

16th c. Andrés Mixcoatl - a rainmaker who became a god.

Martín Ocelotl - a former merchant who became a healer and a prophet.

17th c. Juan Coatl - a visionary healer, a shaman?

Gregorio Juan - a therapist and prophet who became a ManGod? 
18th c. Antonio Pérez - a former shepherd who became a healer, preacher and a God.

\section{6th CENTURY}

Andrés Mixcoatl, a baptised Indian whom I would present shortly as a "rainmaker who became a god". Or in his own words at the interrogation before the Tribunal of the Holy Office of the Inquisition, September 14, 1537:

My name is Andrés. I am a Christian. A friar baptised me at Texcoco five years ago. I don't know his name. I took catechism every day at Texcoco with the friars of St. Francis and their disciples, some young men in their charge. They told us in their sermons to abandon our idols, our idolatry, our rites; to believe in God; and many other things. I confess that, instead of practising what they told me, for three years I have preached and maintained that the brothers' sermons were good for nothing, that I was a god, that the Indians should sacrifice to me and return to the idols and sacrifices of the past. During the rainy season, I made it rain. That is why they presented me with paper, copal, and many other things, including property.

I often preached in plain daylight at Tuláncingo, Huayacocotla, Tututepec, Apan, and many other places. It was at Tetehualco, about four years ago, that I became a god. Since there was no rain, during the night I made magic incantations with copal and other things. The next day it rained a lot. That is why they took me for a god. The chuchumecas executed one of their priests, claiming that he knew nothing and couldn't make it rain. I declare that when I engaged in these superstitions and magic practices, the devil spoke to me and said: "Do this, do that". At Tepetlaoztoc I did the same thing as at Tepehualco; I performed ceremonies, offered copal; it started to rain, and they acknowledged me as a god - it must have been three years ago. (Gruzinski 1989: 36-37)

In Gruzinski's summarising words as follows: Texcoco, 1532: baptism of Andrés; Tepehualco, 1533: Andrés becomes a god; Tepetlaoztoc, 1534: Andrés is a god (ibid. 37). 
Martín Ocelotl - a contemporary of Andrés Mixcoatl but with quite a different background. He became a Christian already in 1525 (Gruzinski 1989: 56). He was probably born in Chiautla, his father was a merchant and his mother had a reputation as a "sorceress" (ibid. 39). Besides his own profession as a merchant he soon extended his activities to include those of a healer and a prophet (ibid. 40). He also seems to have had a fairly good knowledge of pre-Hispanic life and thinking. Together with his preaching mostly on famine and such catastrophic events (ibid. 40), his "apocalyptic anticlericalism" as Gruzinski puts it (ibid. 42) added to his legendary reputation. He was arrested by the Inquisition in February 1537 and brought to trial in Spain where nothing is heard about his destiny there.

His contemporary Andrés Mixcoatl prophesied as follows although referring first and foremost to himself:

Let the magistrates of the Audiencia and the Law say what they will, let them accuse me of whatever they will, I did not myself go to Castile, but I do criss-cross these mountains like the deer and the rabbits [which in pre-Hispanic rhetoric means marginality, nomadic irreverence and nonconformity]. It is quite true that my messenger went to Castile. He will be back. Let us see what the Emperor ordains; and when my messenger returns, I shall begin again to teach the people. (ibid. 43)

So with all his gifts Martín Ocelotl was reduced to a "messenger" by his "colleague" and successor Andrés Mixcoatl. Fusing, however, more or less consciously with his "master" into what might be seen and condemned as "a bluff - a deception" - "for the servant, for the faithful, for Andrés himself, there was nothing contradictory in the merging of Ocelotl and Mixcoatl into a single, identical man-god" (ibid. 43).

Without further comments I personally agree. All the more so considering similar processes of fusion in pre-Hispanic times e. g. that of Quetzalcoatl, the god and his namesake and terrestrial manifestation Quetzalcoatl Topiltzin, governor and high priest at Tollan. 


\section{7th CENTURY}

\section{Gregorio Juan}

At the interrogation, February 19, 1660 Gregorio Juan presents himself as "a native of the village of San Agustín in the parish of Xicotepec. I lived with [my parents] until I was /---/ fourteen years old. Then I ran away from my father /---/" (Gruzinski 1989: 64).

Gregorio became influenced by an Indian with the name of Pedro. He tried to initiate him in his own activities presenting him to his "god" who appeared in a tent in the form of a child "whose skin was dark blue, his face white, and his hair saffron yellow" (ibid. 65).

The child said to me /--- / "this is the liquid you shall give the sick you wish to care for; whenever you need it, call me as Pedro did, and you will find me. Call upon me under the name of Goat or Star, and I shall not fail you; and when you need it, get the water ready and I shall take care of bringing you the powders." (ibid. 66)

When Gregorio declared that he respected the priests because they were the ones who confessed, baptised and celebrated Mass, the child replied:

"Don't accept anything from them. / --- / for I am the true priest. That is why I tell you not to confess." With these words he disappeared. Night had fallen for we had spent the whole day there. (ibid. 66)

Some time later Gregorio called for the child who gave him the prepared water "for me to care for a child named Pedro /---/ The father had asked me to look after his son, whom he had brought to my parents' house. There the potion was prepared and given to the child. Matheo, his father, had known about me because I already had a reputation in the village for looking after the sick" (ibid. 67).

Now this version if compared with those of the authorities, (ibid. 72) and the statements of the neighbours (ibid. 75) merged into what Gruzinski calls "The Many Faces of Gregorio" (ibid. 79-84) and "An Old-Fashioned Man-God" (ibid. 83). 
There is no doubt that Gregorio had therapeutic gifts. Together with catastrophic situation in those days when many deadly sicknesses threatened the native population, especially children, his image of a healer and a shaman was built up and reinforced.

The divinatory and therapeutic practices and the prophetic statements of Gregorio thus took root in a daily life of tragedy and met its urgent concerns, as well as those of Andrés Mixcoatl. (ibid. 88)

\section{Juan Coatl}

Juan Coatl was an Otomí Indian with a Spanish name and a Nahuatl denomination added in a testimony given by a Spaniard in a trial of "idolatrous Indians" in 1665 (Gruzinski 1989: 92).

According to the summary of the inquiry by the tribunal of Puebla "he goes up to the Sierra or the mountain of Tlaxcala, there /---/ he has a cave beside the spring /---/; two crosses mark the spot. At the entrance of the cave he lights candles, and inside he keeps idols, included a painted canvas representing an Indian woman with Indian youths at her feet, adoring her; another canvas delineating a figure with indigenous features, wearing a tilma [a male mantle] with a stick in his hand; [and] two other paintings, one representing four snakes, and the other a coiled serpent /---/. She is their Virgin. They must not believe in the God of the Spaniards or in the Blessed Virgin. /---/ [The Indians] confessed, too, that when the parish priest came to the village Juan reprimanded the children and adults who went to see him: why go to the priest, since he was more than the priest, he spoke with the gods and provided for them what they needed? And he repeated that they should not believe in God but in their idols" (Gruzinski 1989: 93).

Juan Coatl had promised a Spaniard to give him "a good deal of gold and silver - provided I kept a 'fast' consisting in staying away from women for two days before the Ascension /---/" However, Juan Coatl did not keep his promise as he explained some time after when meeting again that the Spaniard "had not kept his fasting promise".

After some time Juan Coatl appeared to the Spaniard in his sleep, telling him to take a message to the people of Huamantla and San 
Juan that "he was no longer angry with them for having revealed his story: a heavy downpour that same day would be a sign. And if the Indian is to be believed, there really was a downpour" (ibid. 92-93).

Juan committed suicide in the prison of the bishopric of Puebla. The Ecclesiastic authorities declared that they had foreseen "the despair which is to be feared in that sort of subject and above all in a figure so perverted by evil spells" (Gruzinski 1989: 92-93).

In the contemporary descriptions one easily finds similarities in events and details between the pre-Hispanic pantheon, e. g. the rain- and fire gods Mixcoatl Camaxtli, and Christian holy figures such as the Virgin Mary, maybe also Joseph considering he is wearing a tilma, the garment of the Aztec macehual 'common man'; and furthermore the appearance of Juan called "protector" telling the adherents what to do - and so on.

The quintessence of the traditions as testemonial reflections of his importance as a leading figure, will be that Juan Coatl had many adherents who believed in him, whether man or god.

A final striking parallel - the patron god of the Otomis in pre-Toltec times was remembered by his Nahuatl name Otonteuhtli and he was considered to have been "hombre divinizado" - deified man. (Paso y Troncoso 1898: $191 \mathrm{ff}$.)

\section{8th CENTURY}

\section{Antonio Pérez}

Antonio Pérez was also called the "Shepherd" because he once kept sheep. He could be classified as a "healer" and a preacher or an "improvised sacristan" (Gruzinski 1989: 113).

At an interrogation, in September 1761, he tells that he once "accompanied a Dominican father whose name he did not know nor where he came from. It could well be that he was the devil". The Dominican, however, condemned him for his heavy drinking and then he 
instructed me in caring for the sick, advising me to use /--- / eggs, soap, milk, cooking oil, mint, or tomato skins depending on the nature of the illness /---/. /---/ For all my treatments, Antonio Pérez continues, I recite the Credo as the Holy Church teaches it / --- / and I add these words: "In the name of the most Holy Trinity, of the Father, the Son and the Holy Ghost, Amen." I put my trust first in God and only then in the herbs. (Gruzinski 1989: 106-107)

It may seem a paradox that this same man is said to have declared to one of his followers: I am God, and it is I who feed the worlds (ibid. 105).

However, by some he was perceived as a god: He had God in his body /--- / he had God in his chest.

To confirm this declaration he proclaimed that "the saints were bad, /---/ they were not helping us, while he received help from the Virgin, from his god who was the Ear of Corn, and from the Three Corns, who were the Most Holy Trinity" (Gruzinski: 122).

To summarise Antonio Pérez's character and programme I borrow the words of Serge Gruzinski when he adduces

the stages of 'deification' of an Indian in whom a new man-god is to be recognized: the sacralisation of his relations with the faithful; the as similation ("He was like God"); the pos session (of God, in his body and especially in his chest); the profession of faith ("I am God").

And the investigator continues "It should not be ruled out that those phases also reflect the range of his followers' interpretations, or even Antonio's changing attitude and uncertainty about his own character". (ibid. 122)

\section{THE INDEPENDENCE ERA (1810) 1823-1910}

For this era I turn exclusively to the areas of the Mayan peoples foremost of historical reasons - however self-contradictory my approach might seem. While Mexicans fought for their independence against the Spaniards and won, the Mayan twenty years later 
fought intensively for their independence against the Mexicans. I am referring to the so-called La guerra de Castas (Caste War) 1817 which was to become the most apotheosised military event of that century.

I have selected just a few outstanding personalities whom I feel urgent to include in my survey. They are prominent chiefs or caudillos, caciques: Jacinto Pat, Cecilio Chi and Manuel Antonio Ay.

The claims of the Mayas, besides land and independence opposed both by ladinos and officials, was equal taxation and contributions to the Church. Those were higher for them than for the ladinos as "they were considered more in need of religion!" (Rugeley 1997: 43; 53)

Jacinto Pat - a rebellion first winning, finally assassinated.

He was a resident of Tihosuco referred to "more than any other village - the cradle of the Caste War" (Rugeley 1997: 22). Its fame as such, however, was competed by the village of Tepich, and others.

He was a member of a family whose reputation for many years was that of utmost importance, thus a prominent figure in the Mayan elite. He started the rebellion in 1847 in co-operation with other prominent Mayas, including Cecilio Chi from Tepich. He led the southern half of the revolutionary armies and he was appointed "Gouveneur" for the Indians of Yucatán - a controversial nomination though. As such he signed the peace treaty in 1848, an arrangement that, however, soon collapsed. (Mossbrucker 1993: 43, $45,53)$ Afterwards the unity of the rebels dissolved. Running short of supplies - gunpowder, salt, meat, clothes, etc. - Pat retreated to the Belizean frontier hoping to find new equipment. There he was assassinated "evidently under the direction of his lieutenant Venancio Pec" (Rugeley 1997: 35).

As late as 1899 several stories and legends were circulating about Jacinto Pat's earlier life, but most of doubtful historical value. However, this legendary figure speaks for himself and there is an impressive statue in a park of Tihosuco (ibid. 29) which bears witness of the high esteem to posterity. 


\section{Cecilio Chi}

Cecilio Chi was not a permanent resident of Tepich until 1847 having lived some years around 1832 in Tihosuco.

His background differed considerably from that of the contemporary leader Jacinto Pat. His geographical mobility put him socially into contact with a much wider socio-political network, while Pat related his activities towards the Yucatecan creoles (Rugeley 1997: 39).

They were both imprisoned in 1839 just when Chi had been nominated batab of Tepich, which indicates a middle position in the ranking Mayan society (Rugeley 1997: 45).

About Cecilio Chi there are many traditional stories told and circulating - more apocryphic than historical, though. Thus it was said that

the war erupted when Cecilio Chi discovered his daughter reduced to concubinage by the local minister! / --- / However, this popular story, like much of oral tradition, probably uses personalistic narratives to symbolise broader social pressures. (Rugeley 1997: 61 note 98)

\section{Manuel Antonio Ay}

Manuel Antonio Ay is from a later part of the Caste War.

As a witness to his importance and his place in the people's memory one may draw the attention to the words on the commemorating monument in his home town Chichimila: (Rugeley 1997: 51)

MANUEL ANTONIO AY

Protomartir de la Revolución Maya de 1847-1975.

\section{THE 20th CENTURY: REVOLUTION 1910}

There are many spectacular personalities whom for want of a specific term I will describe as "apocryphal historical protagonists". They are the main actors of the dramatised life cycle of prominent 


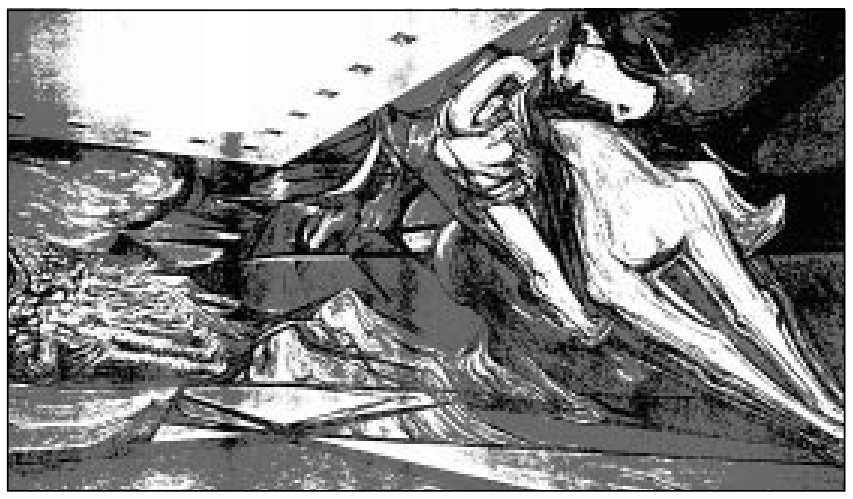

Sala de la revolucion. Pinturas murales por David Alfaro Siqueiros, 1967. Museo Nacional de Historia - Castillo de Chapultepec. México.

figures, factual or fictitious. The stories they appear in are a conglomeration of selected details about these protagonists from their coming into existence (conception and/or birth), their adventurous lives and their cultural and/or political achievements. Over the centuries such stories have been transformed, often magnified according to the socio-political claims of the adherents whether their aims are the benefit of the group and community of their own fulfilment of power.

\section{Tepoztecatl}

In the same way as the politicians of Aztec rulers changed the history of their predecessors or glorified their accomplishments when convenient, so a local community or village lays claims to historical grounds for their important ancestors.

Even in the 1940's Tepoztecatl stands out as an imperishable character in the village's collective mind. His origin may be traced as far back as "Olmec times" although he was more divine than human in those days. After the breakdown of the political hegemony of the Toltecs and the fall of their capital Tula/Tollan, the Aztecs 
also integrated the 400 pulque gods into their own pantheon, naming here only those prominent enough to have their names remembered: Ometochtli and Tepoztecatl (Lewis 1963: 276).

After the Conquest, Tepoztecatl, then an authoritative cacique in Tepoztlán, was strongly influenced by the Spanish dominance and converted to Catholicism. The local god Ometochtli whose image was destroyed by the priests, vanished. The former "King Tepoztecatl" was baptised on the 18th of September, and renamed according to the Catholic calendar, Natividad. However, he was to be better known - and remembered - as El Tepozteco (Lewis 1963: 255).

During the Independence era the State and the Church joined forces to control life on all social levels. The Church organized religious activities in cofradías (brotherhoods) while workmen - inter alia formed gremios in accordance with their distinctive interests and aims. Thus a socio-political setting was created which left little official room for historical or deified heroes.

The revolution changed the situation and at times the image of El Tepozteco alternating with Natividad would show up again. The presumably defeated Ometochtli lured in the background fused with the Aztec god of wind now and then evoking great fear among the local population. Natividad seems to have merged with Tepoztecatl, now El Tepozteco, who was regarded as the son of the Virgin Mary (Lewis 1963: 256).

On the 8th of September the Feast of the Virgin of Natividad is organized. The ceremonies for the Virgin are performed inside the church, while the dances and the traditional speech in honour of her son, El Tepozteco, are held outdoor (Lewis 1963: 461).

As a legendary "deified" figure, there are many tales and stories told about El Tepozteco and his fabulous achievements:

He is said to have been born by a young woman serving in the temple of the god, the father presumably being the god himself. Fearing the king's wrath she left the new-born child at the riverside to be drowned by the waves. But the water refused to do so and the river changed its current. The boy was found by the king's daughter, and the king gave order that the mother should be 
found. However, the search was in vain. Now the king ordered that the child should be thrown to the wild animals in the forest, but the next day he was found sleeping under the pencas, the fleshy leaves of the maguey plant that had united to protect him. Then the king had him thrown to the ants, but the next day the princess found him being fed by the ants with tiny pieces of fruit. Convinced of the boy's supernatural descent the king adopted him. His capacity for learning poetry, as well as the art of fighting and magic were soon manifested. Finally he saved the old king from being sacrificed in the temple of his enemies, and he liberated the country from invaders and gave them prosperity and peace. (Montell 1936: 122-23)

From Milpa Alta another and somewhat different version is told:

There is says that Tepoztecatl/El Tepozteco was miraculously conceived in that his mother got pregnant while washing her clothes in the river near a "cave inhabited by the winds", however, nobody knew that. Her parents got very angry with her, but one night her father dreamed that a young

well dressed man, a city fellow (caxtiltecatl) told him: "Your daughter is about to become a mother. I beg you not to beat her. When the child is born, you will love him dearly. He will grow up and you will find out his true worth." And so it was.

When once visiting the city of Mexico as a young man he lifted the bells of the Cathedral into their places. On his way home, however, the two doves he was carrying in a crate escaped. One went off to sit upon the church of Tepoztlan and the other upon the hill which is the home of Tepoztecatl. (Horcasitas 1972: 1519; cf. 1979: 24 for texts in Nahuatl and Spanish)

Sometimes El Tepozteco is seen as a parallel of contrast to the devil /el pingo/. It is to the devil that the Tepoztecans attribute all evil that befalls them. However, he cannot cause drought, which is conceived as being God's punishment effected through El Tepozteco.

In the 1920's there was a drought in Tepoztlán and surrounding area and the crops were severely threatened. One day

El Tepozteco appeared to a peasant from Yuatepec who was on his way to Tepoztlán. He no longer wore his ancient dress but 
was dressed as a humble peasant in white shirt and calzones and broad-brimmed Zapatista sombrero, and with a handkerchief tied around his neck in typical local fashion.

El Tepozteco spoke to the peasant, saying: "Go and tell my village that I am very angry because they have my mother [the Virgin of Natividad] naked and that is why I have not wanted it to rain. They must buy her a crown and a tunic of silk and satin and then I will send abundant rain."

Then he mysteriously disappeared and the man from Yuatepec hurried to Tepoztlán to tell what had happened. When the news had spread through the village some of the mayordomos of the old cofradias took it upon themselves to collect money to buy the clothing and adornment for the Virgin. A few days later, according to Tepoztecans, it began to rain and the crops were saved. (Lewis 1963: 260)

A story with an equally spectacular effect is told twenty years later after that Mexico had declared war on the Axis and obligatory military service was established:

In those days of worry and confusion, a conscript was walking the streets of Cuernavaca. He was crying, because he had been called to the army. Suddenly at the corner he saw a boy, dressed like a peasant. The boy asked him why he was crying. "Why shouldn't I cry, for I must be a soldier, and they have ordered me to the war to defend the United States, and I must leave my old parents. If I were to fight for my country it would be bad enough but to fight for the gringos..." Then the boy said: "Go in peace. Your tears are not in vain. Neither you nor other young Mexicans will have to go to fight for a foreign government. You will learn to be a soldier, but you will never leave the country. Go to the village of Tepoztlán and take an offering to my mother, the Virgen de la Natividad." Then the boy disappeared mysteriously. The soldier was very impressed by what had happened. He told his parents and they decided to go to Tepoztlán with an offering. After that they began to tell the people of that village what had happened, and everyone understood that El Tepozteco had spoken again. El Tepozteco kept his word, for none of the conscripts went to fight for the United States. (ibid. 260) 
The Tepoztecan children are taught about El Tepozteco thus:

Tepozteco cannot be known; his house is on the hill near El Parque. There he has his house and everything which he needs in his home, but he himself does not appear. He always lives far off among the clouds. He has a mother who is in the church. We say Mass for his mother. His mother is named Tonantzin [Our revered little Mother] and also Natividad. - When they don't give him a good celebration on the eighth of September he sends a great wind; when the celebration is a good one then he does nothing, he is content. Tepozteco is a god who is loveable and cruel. He has only one punishment for the village. / --- / he takes away the water. (Lewis 1963: 276)

From our tumultuous century what personality could be more appropriate than the outstanding figure of Emiliano Zapata - with one curtailment though in that most probably he would have deprecated deification. Remembered, yes, even commemorated, but no more. He would have appreciated Siqueiro's painting of the revolutionary leader on his white horse, and he would have liked the equestrian statue on his grave in Cuauhtla where from horseback he seems to be listening to what the peasant at his feet has to say.

The son of a peasant he became more a horseman himself but never forgot what he had seen of serfdom and exploitation of the landless and the poor farmers on the immense estates in his home province, Morelos. Influenced by the anarchistic trends of that time and by texts such as the journal "Regeneración" published by Ricardo Flores Magón (cf. Avrich 1988: 108) - Zapata was not illiterate - he fought for "land and liberty" leading his peasant army of around 30.000 men when most, first against the dictator Díaz, and then against traitors and usurpators who did not live up to the motto for his revolutionary program presented in the Plan of Ayala "Libertad, Justicia y Ley", 25th of November 1911. (Silva Herzog 1960, I: 240 45; cf. Blanco Moheno 1973 (1970): 116 ff.)

Emiliano Zapata was not the prime politician who saw the revolution in a wider perspective than the situation in Morelos and the problems of the peasants. Thus Eric Wolf, the anthropologist, describes the reasons most plausible for his shortcomings: 
Zapata /--- / had no comprehension of the needs and interests of the industrial workers and never knew how to attract their support. Similarly, the agrarian struggles in Morelos had been fought in the main against Mexican landowners, not against foreigners. The Zapatistas therefore had little understanding for the struggles of Mexican nationalistas to assert Mexico's national integrity in the face of foreign influence and investment. When Zapata attained that insight, in 1917, it was too late /---/. (Wolf 1973: 32)

The revolution degraded more and more into a civil war. Trapped in an ambush on his way to a meeting with the carrancistas, Emiliano Zapata was assassinated in 1919 (Womack 1977: 32024).

Summarising Zapata's life and achievements Wolf quotes Robert Quick from his book on the Mexican Revolution (Bloomington 1960: 292-93):

/--- / the inarticulate, militarily ineffectual Zapata accomplished in death what he could not win in life. His spirit lived on, and in a strange, illogical, but totally Mexican twist of fate, he became the greatest hero of the Revolution. In the hagiography of the Revolution the caudillo of Morelos continues to ride his white charger... (Wolf 1973: 44)

The Mexican anthropologist and linguist Fernando Horcasitas publishes in his "Nahuatl Chronicle of Díaz and Zapata" what one of the few living eyewitnesses told him about what happened when Zapata was killed:

In April 1919, rumors circulate among the refugees in Xochimilco and Mexico City. Zapata is dead! Let us hear our informant's version of the assassination.

The Zapatistas had set up their camp near the mountain El Cerro del Jilguero. They were surrounded there by the troops of the Carrancistas

with no means of escape. /--- / And though he [Zapata] knew he was going to lose, his spirit did not fail him. 
"Follow me," Zapata said, "Until the last cartridge is gone! If they kill me, go away. /--- / And if you do not want to follow me, go up to the highlands and abandon me. Here is enough money for you to live on the road. /.-./"

When his soldiers went away to the highlands, they left Zapata alone at the Cerro del Jilguero. It is said that a trap was set for him. A general by the name of Amaro was the one who betrayed Zapata. "I have come to join you," he said. "I am no longer with Carranza! I am with Zapata now!"

Zapata trusted him. He believed Amaro, who joined the army as if he had been one of Zapata's soldiers. It was then that Amaro killed Zapata. (Horcasitas 1972: 175 ff.)

Zapata is memorised in innumerable legends, traditions, songs and sayings. He was the first to coin the motto "Men of the south, it is better to die standing than live down on your knees". His main revolutionary goal was "Land to the landless" (Bamford Parkes 1940: 350). The semicircular wall that protects the ruins of his home in Anenecuilco bears the famous words "The land belongs to him, who works it!" There I was told by an old guide that the Mexican government, i.e. the PRI in reality, wants to move Zapata's body from his grave in Cuautla in order to solemnly bury him under the Revolutionary Monument in Mexico City but the family refused. Not until the goal of the Mexican Revolution is fulfilled, its greatest hero will remain where he is now.

Since 1994 a liberation movement in Chiapas, Mexico, continues what one could call the silenced struggle for the subdued landless Maya Indians in the very spirit of Zapata. As recruits of the Ejército Zapatista de Liberación Nacional/EZLN the participants quite logically call themselves "zapatistas". Their leader is "Subcomandante Marcos" - idealised by some, maybe even idolised by others.

Ending finally my long though far from complete list of outstanding figures in Mexico I find no personage finer than Nezahualcoyotl, the famous ruler of the Acolhuas in Texcoco 1402-1472: known as a progressive politician, a lawmaker, an ingenious channel constructor, a city planner and builder, a philosopher more than a religious believer and a poet, whose justified fame was intensified 
during the Revolution. Urban districts, educational institutions, cultural centres, streets and squares were named all over Mexico after him and quite rightly too. However, he would have opposed all attention of false religious ceremonialisation and be appalled by the thought of any kind of deification. Indeed the most congenial respect the Mexicans could pay him would be not to divinise him!

On the other hand I think he would have appreciated what I saw and was told in 1963 having climbed to the top of his beloved summer residence of Tezcotzinco (Hellbom 1976: 83). According to the tradition he had a roofless room there dedicated to what one would call "pantheistic contemplation/meditation". There on the very top of the hill just having passed a faded stone face of the rain god Tlaloc I suddenly saw three white crosses. They had been put up there, so I was told, by a very sick man in gratitude of being cured during the night - but nobody knows how. His words of dedication were plainly painted in red as follows:

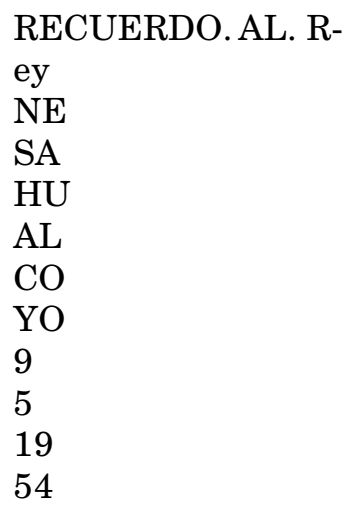

\section{CONCLUSIVE COMMENTS}

My descriptive survey can only result in some preliminary and premature comments.

The figures presented differ essentially as to their character and evaluation in the minds of their adherents. 
This can be due to their double roles and/or dual character; some of them because of their miraculous birth like Huitzilopochtli or supernatural emergence or because of their devastating actions contrary to expectations like Tezcatlipoca, while others because they emanate out of crisis, promising salvation mostly not fulfillers like El Tepozteco and some are "true" gods acting like humans, others humans approaching divinity.

It is easier to say what they are not: they are neither saints nor demons, but some have traits of a saint, while others act like devils.

They are not always worshipped, although sometimes prayed to. Some have existed, others only visioned like emanations of wishful thinking, but all have been shaped in the minds of their believers. Thus some are apotheosised if not deified, others idolised but not enshrined.

In different ways and to different degrees they are all the result of a process of shifting and changing without never reaching the complete transformation from one being to another.

Some are like god Tezcatlipoca who is said to be "disguised" without though, actually renouncing his original identity as a god; others like Coatlicue and Cihuacoatl - in different versions fusing into each others' roles - one as mother of the gods, e. g. Huitzilopochtli, being originally a female human, while the name of the other in late Aztec times was used as the title of the Aztec co-ruler.

Both goddesses were called by their adherents Tonantzin 'Our Revered (Little) Mother', an epithet applied also to other mother goddesses and tantamount to the Spanish "Madrecita", i.e. the Virgin Mary (cf. Schultze-Jena 1957: 408 ff). In December 1531 she appeared to the baptised Indian Juan Diego on the hill of Tepeyac, the very place of a former shrine dedicated to a goddess called "Tonantzin". As "Nuestra Señora de Guadalupe" the Holy Virgin is worshipped not only by the Mexicans. Millions of catholic pilgrims from all parts of the world assemble to pay their reverence to the Mother of Christ, whether actually believing or not in her miraculous image on Juan Diego's tilma (cloak) at her altar. (Hellbom, 1964: 58-72). María may not be a "true goddess" however holy. She is the mother of the Son of man. 


\section{References}

Anales del Museo Nacional, T III. 1886. Sp. trad. G. Mendoza y Felipe Sanches Solis. México.

Avrich, Paul 1988. Anarchist Portraits.

Bamford Parkes, Henry. A History of Mexico. (Sw. trans. 1940.) Stockholm.

Blanco Moheno, Roberto 1973 (1970). Zapata. Mexico.

Brenner, Anita (1943) 1976. The Wind That Swept Mexico. Mexico.

Brotherstone, Gordon 1992. Book of the Fourth World. Reading the Native Americas through their Literature. Cambridge.

Burland, C. A. 1953. Magic Books from Mexico.

Caso, Alfonso 1953. El pueblo del Sol. México.

Chavero, see Anales ...

Clendinnen, Inga 1991. Aztecs: an interpretation. Cambridge.

Davies, Nigel 1977 (1973). The Aztecs. A History. London.

Esplendor del México Antiguo. 1959. México.

$\mathrm{FC}=$ Florentine Codex. 1950. Manuscript in Nahuatl of Fray Bernardino de Sahagún. Trans. J. O.Anderson \& Charles E. Dibble. 12 vols. Santa Fe.

Gillespie, Susan D. 1989. The Atztec Kings. The Construction of Rulership in Mexica History. Arizona.

Gillmor, Frances 1964. The Kings Danced in the Marketplace. Tuscon.

Gonzales, Luis R. 1990. Hernando de Alarcón, Descubridor del Río Colorado y el Retorno de Quetzalocoatl. Historia de la Religión en Mesoamérica y áreas afines. II Coloquio. Edited by Barbro Dahlgren. México, pp. 170-189.

Gruzinski, Serge 1989. Man-Gods in the Mexican Highlands. Indian Power and Colonial Society, 1520-1800.

Hellbom, Anna-Britta 1964. Las Apariciones de la Virgen de Guadalupe en México y en España. Un estudio comparative. ETHNOS. Stockholm.

Hellbom,Anna-Britta 1976. Reflejos de "Sincretismo" en el Valle de México. Actes du XLII Congrés International des Américanistes. Vol. VI. Paris, 73-84.

Hellbom, Anna-Britta 1997. “Todo está cercano y todo está lejano" - Tloque naoaque concepto omnímodo del cosmos.Ideología, cosmovisión y etnicidad a través del pensamiento indígena en las 
Américas. Simp. 7a, ICA48, Stockholm/Uppsala 1994. Bibl.ABYAYALA, Ecuador 1997, pp. 127-151.

Hellbom,Anna-Britta 1997. Tricky Outsiders - Types of a Figure and Figures for Fun in Mexican Cosmolore. Acta Americana, Vol. 5, No. 2, pp. $61-88$.

Horcasitas, Fernando 1972. Life and Death in Milpa Alta. A Nahuatl chronicle of Diaz and Zapata.

Horcasitas, Fernando 1979. Los Cuentos en Nahuatl de Dona Luz Jiménez. Mexico.

Kirtley, Bacil F. 1960. La Llorona and Related Themes. Western Folklore, XIX: 155-168.

León-Portilla, Miguel 1992 (1980). Toltecayotl aspectos de la cultura náhuatl. México.

Lewis, Oscar 1963 (1951). Life in a Mexican village. Tepoztlán restudied. Urbana.

Miller, Mary \& Taube, Karl 1993. The Gods and Symbols of Ancient Mexico and the Maya. An Illustrated Dictionary of Mesoamerican Religion. London.

Molina, Alonso de 1944 (1951 Mexico). Vocabulario en lengua Castellana y Mexicana. Madrid.

Montell, Gösta 1936. Mexikanskt indianliv $i$ forntid och nutid. Stockholm.

Moreno, Manuel M. 1962. La Organización Política y Social de los Aztecas. I. N. A. H. México.

Mossbrucker, Gudrun 1993. Wie ethnische Gruppen "gemacht" werden: Die „Rebellion”. Quistail und der Kastenkrieg (Yucatán, México), Wiener Ethnohistorische Blätter, Heft 38. Wien.

Paso y Troncoso, Francisco del 1898. Descripción, historia y exposición del Códice Pictórico de los Antiguos Nauas que se conserva en la Bibl. de la Cámara de diputados de París. Florencia.

Paz, Octavio 1990. The Labyrinth of Solitude.

Rugeley, Terry 1997. Tihusuco 1800-1847: Municipal Society and the Genesis of the Caste War. Saastun Maya Culture Reviews, No. 1, pp. 19-62

Santamaria, Francisco 1959. Enciclopedia de Mejicanismos. Méjico.

Schultze Jena, Leonhard 1957. Alt-Aztekische Gesänge. Quellenwerke zur alten Geschichte Amerikas VI. Stuttgart.

Silva Herzog, Jesús 1960. Breve Historia de la Revolución Mexicana, Vols. 1, 2. México. 
Townsend, Richard F. 1992. The Aztecs. London.

Wolf, Eric R. 1973 (1969). Peasant Wars of the 20th Century. London.

Womack, John 1977 (1969). Zapata y la Revolución Mexicana. Mexico. 